\title{
Perinatal outcomes in the fetuses diagnosed with hydrops fetalis and isolated pleural effusion
}

\author{
Reyhan Ayaz'1 (D), Oya Demirci² \\ ${ }^{1}$ Department of Perinatology, Faculty of Medicine, Istanbul Medeniyet University, Istanbul, Turkey \\ ${ }^{2}$ Department of Perinatology, Zeynep Kamil Maternity and Pediatric Training and Research Hospital, University of Health Sciences, Istanbul, Turkey
}

\begin{abstract}
Objective: Our study aims to evaluate our clinical experience on and postnatal outcomes of the cases with primary pleural effusion and hydrops who admitted to our clinic.

Methods: In our study, the cases found to have fetal pleural effusion with or without hydrops finding in the second and third trimester between January 2017 and October 2019 were evaluated retrospectively. The patients were examined in terms of the blood types, middle cerebral artery peak systolic velocity and lymphocyte levels in their pleural effusion fluid, and their detailed fetal anatomic screening, fetal echocardiography, karyotyping examination, and TORCH screening in the maternal blood were carried out.

Results: Twelve patients who underwent thoracocentesis and 2 patients who did not undergo thoracocentesis were included in the study. It was found that 6 patients had hydrops and 8 patients had isolated pleural effusion. Postnatal diaphragmatic hernia was detected in 1 of the isolated cases, and it was repaired primarily. Thoracocentesis was carried out in 12 patients except 2 patients. When the effusion relapsed in 6 patients after the first thoracocentesis, the procedure was repeated in 2 patients when the labor was close. While postnatal intubation was not necessary in the newborns that underwent the repeated procedure, 4 patients who did not undergo were intubated. Emergency cesarean section was performed upon the development of fetal distress in a fetus during the second procedure. Postnatal thorax tube was placed to 6 patients who had recurrent pleural effusion. One fetus which had hydrops and whose lymphocyte rate was $1-2 \%$ in the pleural fluid died in the intrauterine period and two newborns died in the postnatal period. No complication developed in 11 patients during the follow-up period which took about 9 months.

Conclusion: Having hydrops fetalis in the presence of fetal pleural effusion and detecting low lymphocyte rate in the pleural fluid affect the prognosis negatively. Performing thoracocentesis in the presence of pleural effusion together with or without hydrops and repeating the procedure when the labor is close have a positive impact on the perinatal outcomes. The families should be recommended intrauterine fetal treatment for the appropriate cases and the labor should be planned in a tertiary center.
\end{abstract}

Keywords: Pleural effusion, hydrops, thoracocentesis.

\section{Özet: Hidrops fetalis ve izole plevral effüzyon saptanan fetüslerde perinatal sonuçlar}

Amaç: Kliniğimize başvuran primer plevral effüzyon ve hidrops gelişen olgularda klinik deneyimimiz ve postnatal sonuçların değerlendirilmesidir.

Yöntem: Çalışmada Ocak 2017 - Ekim 2019 tarihleri arasında ikinci ve üçüncü dönemde hidrops bulgusu olan veya olmayan fetal plevral effüzyon saptanan olgular retrospektif olarak incelendi. Hastalar kan grupları, orta serebral arter pik sistolik velositesi ve plevral effüzyon sıvısında lenfosit düzeyi yönünden incelendi ve hastaların ayrıntılı fetal anatomik taraması, fetal ekokardiyografisi, karyotip incelemesi ve maternal kanda TORCH tetkikleri yapildi.

Bulgular: Çalışmaya torakosentez uygulanan 12, uygulanmayan 2 hasta alındı. 6 hasta hidrops fetalis, 8 hasta izole plevral effüzyon olarak değerlendirildi. İzole olguların 1 tanesinde postnatal diyafram hernisi saptandı ve primer onarıldı. 2 hasta hariç 12 hastaya torakosentez yapıldı. Birinci torakosentez sonrası 6 hastada effüzyon tekrarı olması üzerine 2 hastaya doğuma yakın işlem tekrarı gerçekleştirildi. İşlem tekrarı yapılan bebeklerde postnatal entübasyon gerekmezken, yapilmayan 4 hasta entübe edildi. 2. işlem s1rasında bir fetüste fetal distres gelişmesi üzerine acil sezaryen ile doğum yaptırıldı. Tekrarlayan plevral effüzyonu olan 6 hastaya postnatal toraks tüpü takıldı. Hidrops olan ve plevral sıvıdaki lenfosit oranı \% 1-2 olan bir fetüs intrauterin, iki bebek postnatal dönemde kaybedildi. Ortalama 9 aylık izlem sürecinde 11 hastada komplikasyon gelişmedi.

Sonuç: Fetal plevral effüzyon varlı̆̆ında hidrops fetalis olması, plevral sıvıda lenfosit oranın düşük saptanması prognozu olumsuz etkilemektedir. Hidropsla birlikte olan ya da olmayan plevral effüzyon varlığında torakosentez uygulanması ve doğuma yakın tekrarlanması perinatal sonuçlar üzerine olumlu etkisi olmaktadır. İntrauterin fetal tedavi uygun olgularda ailelere önerilmeli ve doğumun 3. basamakta yapilması planlanmalıdır.

Anahtar sözcükler: Plevral effüzyon, hidrops, torakosentez.

Correspondence: Reyhan Ayaz, MD. Department of Perinatology, Faculty of Medicine, Istanbul Medeniyet University, Istanbul, Turkey. e-mail: drreyhanayaz@hotmail.com / Received: December 7, 2019; Accepted: December 31, 2019

Please cite this article as: Ayaz R, Demirci O. Perinatal outcomes in the fetuses diagnosed with hydrops fetalis and isolated pleural effusion. Perinatal Journal 2019;27(3):183-188. doi:10.2399/prn.19.0273010 


\section{Introduction}

Fetal primary pleural effusion (PE) is the accumulation of fluid in the pleural cavity, and it is called as hydrothorax in the antenatal period and chylothorax in the postnatal period. It is a rare condition with an incidence of $1 / 15,000{ }^{[1]}$ Its clinical course varies, and it may regress spontaneously or result in fetal death. Its optimal treatment method is unclear. ${ }^{[2]}$

Primary hydrothorax develops after the leakage of lymphatic fluid between parietal and visceral pleural membrane as a result of the increased intrathoracic pressure, and it can be unilateral or bilateral. Most of the cases are displayed ultrasonographically as anechoic fluid collection in the pleural area in the third trimester. ${ }^{[3]}$ It may be a part of the non-immune hydrops fetalis. The pleural effusion developing in association with infections, fetal anemia, chromosomal diseases, fetal malformations and intrathoracic masses (cystic adenomatoid malformation, diaphragmatic hernia, etc.) are defined as the secondary pleural effusion. ${ }^{[4,5]}$ Depending on the severity of the pleural effusion, the esophagus undergoes pressure and congestive heart failure develops, and secondary polyhydramnios, disruption in the venous return and hydrops develop. ${ }^{[6-11]}$

The development of pleural effusion in the early weeks of gestation, presence of hydrops findings and preterm labor are associated with the poor prognosis. ${ }^{[1,6]}$ The prognosis changes in the secondary PE depending on the underlying cause. It was reported that performing drainage in the cases with hydrops, severe pleural effusion, mediastinal shift and polyhydramnios improves the perinatal outcomes. ${ }^{[12-14]}$ It is known that neonatal mortality increases in the cases, who do not undergo any intervention, due to pulmonary immaturity and preterm labor. ${ }^{[15]}$ The treatment options are controversial as it is a rare finding, and therefore the methods such as thoracocentesis, thoracoamniotic shunt, and pleurodesis by OK-432 can be used for treatment purposes. Thoracocentesis is recommended in order to help neonatal resuscitation before labor for both diagnostic and treatment purposes. ${ }^{[16]}$

In this study, we aimed to evaluate our clinical experience on and postnatal outcomes of the cases with primary pleural effusion and hydrops that we performed thoracocentesis.

\section{Methods}

The cases with or without hydrops finding and found to have fetal pleural effusion at the second and third trimesters in the Perinatology Clinics of Zeynep Kamil Maternity and Pediatric Training and Research Hospital of the University of Health Sciences and Medeniyet University between January 2017 and October 2019 were included in the study. The data of the newborns during pregnancy and postnatal period were accessed from the hospital database retrospectively. Hydrops, was considered as the fluid accumulation, coexisting with the pleural effusion, in the multiple areas such as pericardium, subcutaneous regions and abdomen. The patients were examined and checked in the antenatal period for blood types, detailed fetal anatomic screening, middle cerebral artery peak systolic velocity (PSV) to rule out the fetal anemia by Doppler ultrasonography, fetal echocardiography, lymphocyte level in the pleural effusion fluid, and CMV, Parvovirus, Toxoplasma, Syphilis, Rubella, Herpes simplex immunoglobulin $M$ and immunoglobulin $G$. Conventional karyotyping was carried out but array CGH was not evaluated. The data on the maternal age, gravida, parity, week of gestation during treatment, lymphocyte rate in the pleural fluid, delivery week, and thoracocentesis number were obtained from the hospital records. The birth weight, Apgar scores, the need for postnatal thorax tube, sex, delivery type, the period between thoracocentesis and labor, hospitalization period at the newborn intensive care unit and intubation period were evaluated. Thoracocentesis procedure was carried out on the fetuses only meeting following criteria: (1) the cases having pleural effusion previously and progressing to hydrops, and which were thought that the reason of hydrops was the isolated pleural effusion, (2) the presence of fluid in more than $50 \%$ of the rib cage causing repulsion in the mediastinum without hydrops, (3) the cases developing polyhydramnios quickly $(8 \mathrm{~cm}$ above the deepest vertical pocket or $25 \mathrm{~cm}$ above the total amniotic fluid index), (4) the cases without any structural anomaly in other organs or systems, and (4) the fetuses with bilateral hydrothorax. After the patients and their spouses were informed in detail and their informed consents were obtained, pleural effusion was discharged from the right and/or left thoracic cavities of the fetuses by the ultrasound-guided 20-G amniocentesis needle. A second thoracocentesis procedure was recommended for the cases with severe pleural effusion before the labor, and it was performed in the cases who accepted the recommendation. As a routine practice, all patients were administered prophylactic antibiotic before the procedure, indomethacin before 32 weeks of gestation, nifedipine after 32 weeks of gestation and betamethasone with 24 
hour intervals for lung maturation 48 hours before the procedure in the cases between 24 and 34 weeks of gestation. The amnioreduction was performed after the thoracocentesis in cases with polyhydramnios. The cases were informed about preterm premature rupture of membrane, preterm labor, ablatio placenta and chorioamnionitis that may develop after the procedure. The patients were evaluated by weekly ultrasonography for pleural effusion recurrence and fetal well-being tests. The cesarean section was carried out not due to hydrops but only obstetric purposes. Necessary precautions were taken to make pediatrician available and to perform thorax shunt if needed. Thorax tube was applied in the cases which were found to have overt pleural effusion causing respiratory distress during neonatal period.

Descriptive statistical method was used to analyze the data. The data were presented as median (minimum-maximum), mean ( \pm standard deviation), and number (percentage). SPSS version 24 (Statistical Package for the Social Sciences; SPSS Inc., Chicago, IL, USA) was used for the data analysis.

\section{Results}

A total of 14 cases were included in the study. Two patients did not undergo thoracocentesis. Minimal pleural effusion was detected at 20 weeks of gestation in one of them, and it disappeared completely during the followup. Other patient admitted during active labor phase at 37 weeks of gestation, and postnatal thorax shunt was applied. While isolated pleural effusion was found in 8 $(51.8 \%)$ cases, $6(42.9 \%)$ patients had hydrops finding (Fig. 1). In isolated cases and hydrops cases, thoracocentesis week was $30.8( \pm 3.6)$ and $30.6( \pm 1.51)$, mean maternal age was $26( \pm 3.89)$ and $31( \pm 3.74)$, respectively. The procedure was repeated half an hour before the procedure in two patients. Left pleural effusion was found in 1 (7.1\%) fetus, right pleural effusion in $5(35.7 \%)$ fetuses and bilateral pleural effusion in the remaining 8 (57.2\%) fetuses. One fetus died in the intrauterine period and two (15.4\%) newborns in the postnatal period. The lymphocyte rate was found over $80 \%$ in the pleural fluid samples of $71.5 \%$ of the cases, and they were considered chylothorax. The three cases that died had hydrops findings in which anasarca-like edema developed. The leukocyte rate in the thoracentesis fluid of these cases was $1-2 \%$. Among the living newborns, only one case had leucocyte rate less than $1 \%$. Hydrops was seen in 3 of 11 living 11 patients. These 3 hydrops cases were discharged with a full recovery. The mean week of gestation was 35 (range: 31-39), and all patients developing hydrops delivered before 37 weeks (Table 1). While 9 patients delivered by cesarean section, 5 patients delivered by normal spontaneous labor. The cesarean section was carried out in 4 (28.5\%) patients due to acute fetal distress, and two of them resulted in postnatal death. Six patients were recommended a second thoracocentesis procedure before the labor, but only two patients accepted the procedure. Thoracocentesis was not applied before the labor in one patient as she admitted at the active labor phase. While postnatal intubation was conducted in 4 patients who did not accept the procedure, intubation was not needed in two patients who underwent a second procedure. Thorax tube was inserted in 6 patients during the postnatal period including 2 patients who underwent thoracocentesis again when the labor was close. A small $(2 \mathrm{~cm})$ diaphragmatic hernia was detected after the labor in the patient no. 3, and it was repaired primarily (Table 2). Hepatomegaly was detected in the patients no. 1 and 2 which resulted in postnatal death, and they were lost after the acute disseminated intravascular coagulation on the first postnatal day. The emergency cesarean section was carried out due to the acute fetal distress during second thoracocentesis procedure in the patient no. 5. No maternal complication developed during any thoracocentesis procedure. Of 13 cases which underwent thoracocentesis, $53.9 \%$ had preterm labor at and before 37 weeks of gestation. The survival rate was $71 \%(5 / 7)$ among those born prematurely, and $100 \%(6 / 6)$ among those born at term. The karyotype result was normal in all 14 cases.

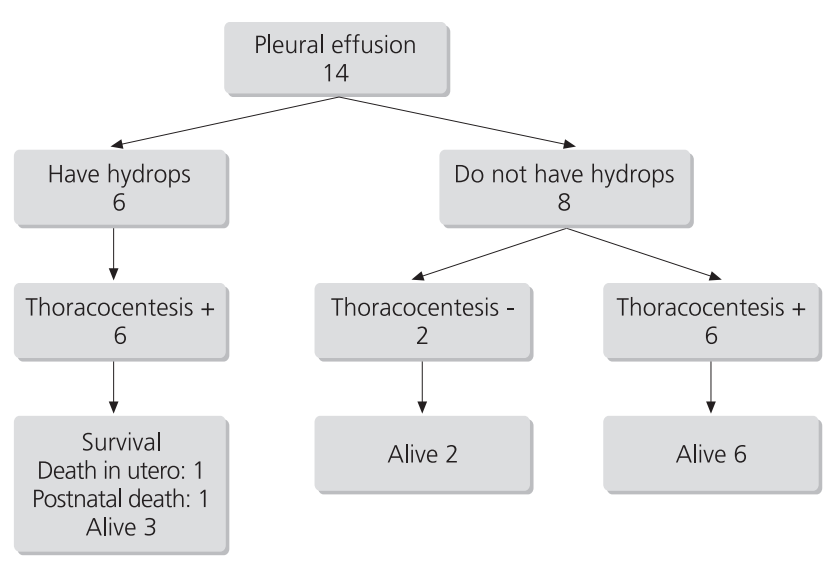

Fig. 1. Postnatal survival results of the pleural effusion cases with and without hydrops. 
Table 1. Maternal profile and pre-treatment characteristics of living and dead fetuses.

\begin{tabular}{|c|c|c|c|c|c|c|c|c|c|}
\hline $\begin{array}{l}\text { Patient } \\
\text { no. }\end{array}$ & $\begin{array}{c}\text { Maternal } \\
\text { age }\end{array}$ & Parity & $\begin{array}{l}\text { Lymphocyte } \\
\text { percentage }\end{array}$ & $\begin{array}{c}\text { PE } \\
\text { localization }\end{array}$ & Hydrops & Polyhydramnios & $\begin{array}{c}\text { TC } \\
\text { week }\end{array}$ & $\begin{array}{c}\text { TC } \\
\text { number }\end{array}$ & $\begin{array}{c}\text { Week of } \\
\text { gestation }\end{array}$ \\
\hline \multicolumn{10}{|l|}{ Living } \\
\hline 1 & 24 & 1 & 88 & Bilateral & - & + & $30-31$ & 2 & 38 \\
\hline 2 & 26 & 1 & 97.5 & Bilateral & - & - & 33 & 1 & $33+4$ \\
\hline 3 & 23 & 1 & 93.2 & Left & - & - & 24 & 1 & 39 \\
\hline 4 & 29 & 2 & 97 & Bilateral & + & + & $30+4$ & 1 & $31+3$ \\
\hline 5 & 34 & 1 & 97.2 & Right & - & + & $32-34$ & 2 & 34 \\
\hline 6 & 36 & 2 & $<\% 1$ & Bilateral & + & - & $33-34$ & 2 & 34 \\
\hline 7 & 26 & 3 & 89 & Right & - & - & - & - & $37+3$ \\
\hline 8 & 24 & 1 & - & Right & - & - & - & - & 39 \\
\hline 9 & 22 & 2 & 87 & Right & - & - & 34 & 1 & 37 \\
\hline 10 & 31 & 2 & 86 & Bilateral & + & + & 29 & 1 & 35 \\
\hline 11 & 29 & 3 & 84.5 & Right & - & + & 32 & 1 & 37 \\
\hline \multicolumn{10}{|l|}{ Dead } \\
\hline 1 & 33 & 3 & $<\% 1$ & Bilateral & + & + & 30 & 1 & 31 \\
\hline 2 & 25 & 2 & $<\% 1$ & Bilateral & + & + & 32 & 1 & 33 \\
\hline 3 & 32 & 2 & $<\% 2$ & Bilateral & + & + & 30 & 1 & 32 \\
\hline
\end{tabular}

PE: pleural effusion; TC: thoracocentesis.

\section{Discussion}

Hydrops or isolated pleural effusion is a condition associated with distinct perinatal mortality and morbidity. While some of them regresses spontaneously, poor perinatal outcomes may develop in the progressive cases. ${ }^{[15]}$ In their prospective study, Ruano et al. found structural and chromosomal anomalies in $75 \%$ of the cases with pleural effusion and showed that the most important parameter affecting survival in pleural effusion is the presence of additional anomalies. It is known that the prognosis is poorer in secondary pleural effusion cases with fetal malformations such as chromosomal or cardiac anomalies. Therefore, identifying the etiological reasons in the fetuses found to

Table 2. Perinatal outcomes of the patients with pleural effusion.

\begin{tabular}{|c|c|c|c|c|c|c|c|c|}
\hline $\begin{array}{l}\text { Patient } \\
\text { no. }\end{array}$ & Sex & $\begin{array}{l}\text { The interval between } \\
\text { TC and labor }\end{array}$ & $\begin{array}{l}\text { Delivery } \\
\text { type }\end{array}$ & $\begin{array}{l}\text { CS } \\
\text { Ind }\end{array}$ & $\begin{array}{l}\text { Birth weight } \\
\text { (g) }\end{array}$ & $\begin{array}{l}\text { Hospitalization } \\
\text { period at NICU }\end{array}$ & $\begin{array}{l}\text { Postnatal } \\
\text { thorax tube }\end{array}$ & $\begin{array}{c}\text { Int } \\
\text { period }\end{array}$ \\
\hline \multicolumn{9}{|l|}{ Living } \\
\hline 1 & Female & 56 & Nsd & & 2620 & - & - & - \\
\hline 2 & Male & 3 & Cs & FD & 2480 & 135 & 71 & 21 \\
\hline 3 & Male & 105 & Nsd & & 3100 & 7 & - & - \\
\hline 4 & Female & 7 & $\mathrm{Cs}$ & FD & 2025 & 41 & 12 & 11 \\
\hline 5 & Female & 14 & $\mathrm{Cs}$ & $\mathrm{FD}$ & 2240 & 9 & 5 & - \\
\hline 6 & Female & 7 & Cs & Previous & 2200 & 71 & 31 & - \\
\hline 7 & Female & - & Nsd & & 3500 & - & - & - \\
\hline 8 & Female & - & Nsd & & 3250 & - & - & - \\
\hline 9 & Female & 21 & Cs & Previous & 3480 & - & - & - \\
\hline 10 & Male & 42 & Cs & Previous - cord prolapse & 2730 & - & - & - \\
\hline 11 & Female & 35 & $\mathrm{Cs}$ & Previous & 2990 & 4 & - & - \\
\hline \multicolumn{9}{|c|}{ Pre- or postnatal dead } \\
\hline 1 & Male & 7 & $\mathrm{Cs}$ & $\mathrm{FD}$ & 1500 & 2 & 1 & 1 \\
\hline 2 & Female & 7 & Cs & FD & 1610 & 1 & 1 & 1 \\
\hline 3 & Male & 14 & Nsd & & 1540 & - & - & - \\
\hline
\end{tabular}

Cs: Cesarean section; Cs Ind: Cesarean section indication; FD: fetal distress; Int: intubation; NICU: newborn intensive care unit; Nsd: normal spontaneous delivery. 
have fetal hydrothorax has a significant role in determining the prognosis and managing the patients. ${ }^{[2,3]}$

Administering the treatment depends on the week of gestation, progression rate, hydrops development and maternal symptoms. Primary, small and non-hydropic effusions can be kept waiting without treatment as they may regress spontaneously. It is recommended following up by weekly sonography when the effusion is in the less than the half of fetal lung, does not cause mediastinal shift and regresses spontaneously during follow-ups. ${ }^{[2,14]}$ Mediastinal shift, rapidly increasing effusion, and the presence of hydrops and/or polyhydroamnios requires drainage. Thoracocentesis and thoracoamniotic shunt are the most common drainage methods. The third but less preferred method is the injection of sclerosing agent into pleural area, which is called pleurodesis. ${ }^{[17]}$ The lungs expanse upon the drainage, and pulmonary hypoplasia risk decreases, venous return increases and hydrops may regress. Fetal deglutition secondary to esophagus decompression becomes easy and the risks of polyhydramnios, preterm labor and premature rupture of membrane may decrease. ${ }^{[2,18,19]}$ In our case series, carrying out prenatal thoracocentesis in hydropic and/or non-hydropic cases affected prognosis positively. The initial treatment is the drainage of fetal pleural effusion by the ultrasound-guided aspiration needle. Thoracoamniotic shunt is particularly preferred in the cases with effusion repeating after drainage or with wide pleural effusion. ${ }^{[5]}$ Some studies recommend a gradual approach for the management of pleural effusion. The first step is the follow-up, and to perform thoracocentesis if pleural effusion exacerbates, and to apply shunt in cases with recurring effusion after the thoracocentesis. ${ }^{[19]}$ We also followed up a case with minimal effusion without carrying out any procedure, and observed that the effusion disappeared completely 2 weeks later. We found that the effusion disappeared completely within 2-4 weeks in 4 of 6 cases who did not have hydrops, had distinct pleural effusion and underwent thoracocentesis.

Derderian et al. showed that the cases, which are unilateral but progressing towards bilateral effusion and hydrops, result in mortality in a short time unless thoracocentesis or shunt is applied. Similarly, there are studies showing that short-time drainages in chylous pleural effusions may be beneficial in some patients and shunt is not necessary. ${ }^{[18]}$ We believe that preferring thoracocentesis as the first treatment option would be appropriate particularly in the cases with primary pleural effusion without hydrops fetalis, because shunt-associated com- plications are more frequent. In a study, the authors reported that the cases particularly which underwent thoracoamniotic shunt before 21 weeks of gestation have the risk of chest wall deformity. ${ }^{[20]}$ The migration or displacement of the shunt is the other complication. Premature rupture of membrane, chorioamnionitis, chorioamniotic separation, preterm labor, fetal hemorrhage, ablatio placenta, cord damage during insertion, and scar development are more frequent in fetuses which were inserted shunt. ${ }^{[2]}$

Today, there is no randomized controlled study comparing intrauterine treatment methods. A review study consisting of 203 patients found that shunt procedure is superior to thoracocentesis, but did not find it statistically significant. While survival rate was $62 \%$ and $82 \%$ for the cases with and without hydrops, respectively, it was $50 \%$ and $77 \%$ for the cases with and without hydrops, respectively, which underwent thoracocentesis. ${ }^{[12]} \mathrm{It}$ should be taken into consideration that there is a risk of preterm labor and premature rupture of membrane secondary to the prenatal invasive procedures, but there may be perinatal losses due to pulmonary immaturity if the procedure is not performed. In our case series, $57 \%$ of the cases were born in preterm labor and $28 \%$ of these cases died prenatally and all of those born at term lived. The premature rupture of membrane developed in two patients, and these two patients later delivered by cesarean section between 35 and 31 weeks of gestation due to the cord prolapse and fetal distress. In the study of Carr et al., 10 patients underwent invasive procedure at the prenatal period and other 11 fetuses were included in the study as the control group. The authors found that Apgar scores were better and the duration of using ventilator was shorter in the patients which underwent thoracocentesis and/or were inserted shunt compared to the control group. ${ }^{[21]}$ In our two cases, thoracocentesis procedure was performed 1 hour before the labor and these two fetuses did not need intubation after the birth. Other 4 patients, who did not accept repeating thoracocentesis procedure when the labor was close, were intubated postnatally, and two of these patients died on the first postnatal day.

Pleural effusion recurred in 6 patients after the thoracocentesis, and thorax tube was inserted in these patients after the delivery. The total survival rate was $78.5 \%$ in our study. The common findings in all babies which died are the presence of hydrops and the lymphocyte rate in the pleural effusion being below $2 \%$. Hepatomegaly and disseminated intravascular coagulation developed in two 
cases which died postnatally. This makes us think that the reason of hydrops may be a metabolic disease. The mean follow-up period of the patients is 9 months, and no health problem was observed after the discharge in the cases discharged with full recovery.

\section{Conclusion}

Primary hydrothorax should not be considered as an indication for the termination of pregnancy. The presence of hydrops is a poor prognostic factor for fetus. Thoracocentesis or shunt options should be considered by taking various parameters into consideration such as the week of gestation, hydrothorax being isolated or coexisting with hydrops, or fast recurrence. The family should be informed about maternal or fetal complications that may develop due to invasive procedures. Performing thoracocentesis when the labor is close should be recommended for the cases with recurring pleural effusion since it decreases the need for intubation of fetus at the newborn period and unilateral thorax tube can be inserted instead of a bilateral one. The differential diagnosis should be performed in the hydrothorax cases detected in the prenatal period, necessary invasive procedures should be performed and it should be planned to carry out the labor in tertiary hospitals where it is possible to insert emergency thorax tube.

Conflicts of Interest: No conflicts declared.

\section{References}

1. Longaker MT, Laberge JM, Dansereau J, Langer JC, Crombleholme TM, Callen PW, et al. Primary fetal hydrothorax: natural history and management. J Pediatr Surg 1989;24: $573-6$.

2. Picone O, Benachi A, Mandelbrot L, Ruano R, Dumez Y, Dommergues M. Thoracoamniotic shunting for fetal pleural effusions with hydrops. Am J Obstet Gynecol 2004;191:204750.

3. Ruano R, Ramalho AS, Cardoso AK, Moise K Jr, Zugaib M. Prenatal diagnosis and natural history of fetuses presenting with pleural effusion. Prenat Diagn 2011;31:496-9.

4. Aubard Y, Derouineau I, Aubard V, Chalifour V, Preux PM. Primary fetal hydrothorax: a literature review and proposed antenatal clinical strategy. Fetal Diagn Ther 1998;13:325-33.
5. Rustico MA, Lanna M, Coviello D, Smoleniec J, Nicolini U. Fetal pleural effusion. Prenat Diagn 2007;27:793-9.

6. Nicolaides KH, Azar GB. Thoraco-amniotic shunting. Fetal Diagn Ther 1990;5:153-64.

7. Yamamoto M, Insunza A, Carrillo J, Caicedo LA, Paiva E, Ville Y. Intrathoracic pressure in congenital chylothorax: keystone for the rationale of thoracoamniotic shunting? Fetal Diagn Ther 2007;22:169-71.

8. Weber AM, Philipson EH. Fetal pleural effusion: a review and meta-analysis for prognostic indicators. Obstet Gynecol 1992; 79:281-6.

9. Waller K, Chaithongwongwatthana S, Yamasmit W, Donnenfeld AE. Chromosomal abnormalities among 246 fetuses with pleural effusions detected on prenatal ultrasound examination: factors associated with an increased risk of aneuploidy. Genet Med 2005;7:417-21.

10. Pijpers L, Reuss A, Stewart PA, Wladimiroff JW. Noninvasive management of isolated bilateral fetal hydrothorax. Am J Obstet Gynecol 1989;161:330-2.

11. Smoleniec J, James D. Predictive value of pleural effusions in fetal hydrops. Fetal Diagn Ther 1995;10:95-100.

12. Castillo RA, Devoe LD, Falls G, Holzman GB, Hadi HA, Fadel HE. Pleural effusions and pulmonary hypoplasia. Am J Obstet Gynecol 1987;157:1252-5.

13. Pettersen HN, Nicolaides KH. Pleural effusions. In: Fisk NM, Moise KJ, editors. Pleural effusions. Cambridge: Cambridge University Press; 1997. p. 261-72.

14. Smith RP, Illanes S, Denbow ML, Soothill PW. Outcome of fetal pleural effusions treated by thoracoamniotic shunting. Ultrasound Obstet Gynecol 2005;26:63-6.

15. Klam S,Bigras JL, Hudon L. Predicting outcome in primary fetal hydrothorax. Fetal Diagn Ther 2005;20:366-70.

16. Cardwell MS. Aspiration of fetal pleural effusions or ascites may improve neonatal resuscitation. South Med J 1996;89: $177-8$.

17. Okawa T, Takano Y, Fujimori K, Yanagida K, Sato A. A new fetal therapy for chylothorax: pleurodesis with OK-432. Ultrasound Obstet Gynecol 2001;18:376-7.

18. Derderian SC, Trivedi S, Farrell J, Keller RL, Rand L, Goldstein R, et al. Outcomes of fetal intervention for primary hydrothorax. J Pediatr Surg 2014;49:900-3.

19. Yinon Y, Kelly E, Ryan G. Fetal pleural effusions. Best Pract Res Clin Obstet Gynaecol 2008;22:77-96.

20. Merchant AM, Peranteau W, Wilson RD, Johnson MP, Bebbington MW, Hedrick HL, et al. Postnatal chest wall deformities after fetal thoracoamniotic shunting for congenital cystic adenomatoid malformation. Fetal Diagn Ther 2007;22: 435-9.

21. Carr BD, Sampang L, Church JT, Mon RA, Gadepalli SK, Attar MA, et al. Fetal intervention for congenital chylothorax is associated with improved outcomes in early life. J Surg Res 2018;231:361-5.

Bu makalenin kullanım izni Creative Commons Attribution-NoCommercial-NoDerivs 3.0 Unported (CC BY-NC-ND3.0) lisansı aracılı̆̆ılyla bedelsiz sunulmaktadir. / This work is licensed under the Creative Commons Attribution-NonCommercial-NoDerivs 3.0 Unported (CC BY-NC-ND3.0) License. To view a copy of this license, visit http://creativecommons.org/licenses/by-nc-nd/3.0/ or send a letter to Creative Commons, PO Box 1866, Mountain View, CA 94042, USA. 